\title{
Organ mercury levels in infants with omphaloceles treated with organic mercurial antiseptic
}

\author{
D. G. FAGAN, J. S. PRITCHARD, T. W. CLARKSON, AND M. R. GREENWOOD
}

From the Departments of Pathology and Neurology, the Hospital for Sick Children, Toronto, Canada, and the Environmental Health Sciences Center, University of Rochester School of Medicine, Rochester, N.Y., $U S A$

SUMMARY Samples of fresh and fixed tissues from infants with exomphalos treated by thiomersal application were analysed for mercury content. The results showed that thiomersal can induce blood and organ levels of organic mercury which are well in excess of the minimum toxic level in adults and fetuses. The analysis of fresh and fixed tissues must be carefully controlled against normal tissues in order to interpret mercury levels accurately.

The introduction of the application of $0.1 \%$ tincture of Thimerosal (thiomersal)* in the treatment of exomphalos is generally attributed to Grob (1957). No unequivocal cases of organic mercury poisoning have been reported after its use in patients with exomphalos though several cases of 'pink disease' have been reported (Schippan and Wehran, 1968; Stanley-Brown and Frank, 1971), as well as a case of 'mercury intoxication' (Leenders et al., 1974). This is thought to be an idiosyncratic reaction unrelated to excessive dosage and should be distinguished from true poisoning.

Analysis of fresh tissue samples obtained at necropsy from an infant with exomphalos treated by thiomersal application who died unexpectedly showed raised tissue levels of mercury. This prompted us to search the records at the Hospital for Sick Children, Toronto, for other mercury-treated cases of exomphalos and carry out organ mercury analysis.

\section{Materials and methods}

Between 1969 and 1975 there had been 13 cases of exomphalos treated by thiomersal application. 10 had died and 9 of these had necropsy examinations. Formalin-fixed wet tissues were available from 6 of the 9. Mercury assays had been carried out in 1972 on fresh tissues from 2 of these 6 cases by the Public Health Division of the Department of Health,

Received 2 May 1977

*The sodium salt of orthocarboxyphenylthioethyl mercury, or sodium mercurithiosalicylate, is the active ingredient of Merthiolate, Lilly, and contains approximately $49 \%$ mercury by weight.
Toronto, using similar methods to those described below.

We performed organ mercury assays on three sets of fresh tissue samples and six sets of formalin-fixed tissues. Cold vapour atomic absorption was used to measure total mercury in blood (Magos and Clarkson, 1972). Solid tissues were weighed and homogenized in $0.9 \% \mathrm{w} / \mathrm{v}$ sodium chloride solutions $(1.0 \mathrm{~g}$ tissue to $9 \mathrm{ml}$ sodium chloride solution). Aliquots from the homogenate were treated and measured as described for hair samples by Giovanoli-Jakubczak ct al. (1974). Samples of the mercury-contaminated omphalocele sac were not stored or transported in the same container as any of the analysed samples.

\section{Results}

Table 1 shows that all 3 cases in which fresh tissue analysis was performed had absorbed an excessive load of mercury ranging from 65 to 2700 times the normal tissue levels. The fresh organ levels in Cases 2 and 3 suggest that the blood levels were similar to or, perhaps in Case 3, even higher than the level of $1340 \mathrm{ppb}$ (parts per billion) found in Case 1. Mercury assays were repeated on the formalin-fixed tissues of the 3 cases in which fresh tissue assays had been performed, and the results are shown in Table 2 with those from the other fixed and stored samples.

These results show a general increase in mercury concentration after fixation which appears to be related more to the duration of storage than to the total dose administered. The mercury content of the formalin fixative was negligible, $<6 \mathrm{ppb}$. Although analysis of all the samples indicated an excessive load 
Table 1 Concentrations of total mercury on fresh necropsy tissues and data from published reports on normal and toxic tissue levels. All concentrations of $\mathrm{Hg}$ are expressed in $\mathrm{ng} / \mathrm{ml}$ and $\mathrm{ng} / \mathrm{g}$ (ppb) fresh tissue

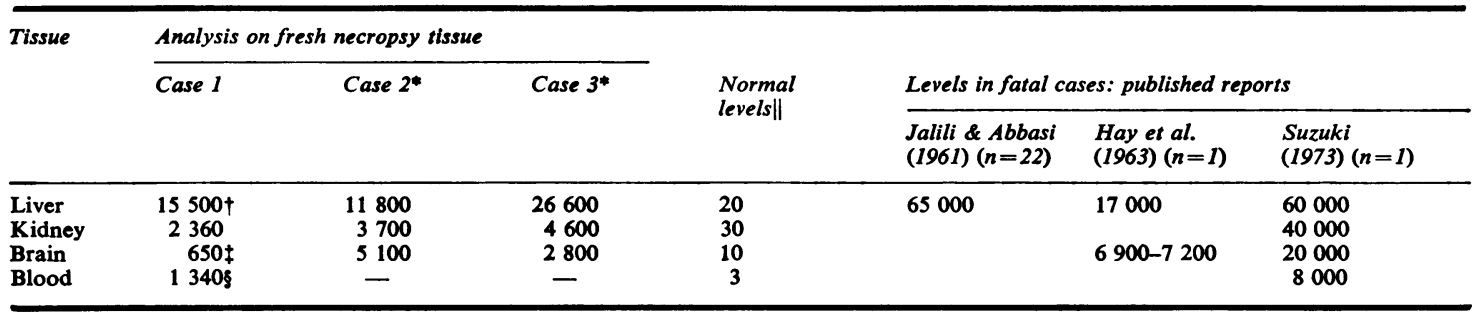

*Data kindly supplied by Dr. G. J. Stopps, Ontario Dept. of Public Health.

tLiver beneath omphalocele membrane.

†Sample taken from cerebellum. Levels from other regions of the brain ranged from $460-1140 \mathrm{ng} / \mathrm{g}$.

\$Collected after death.

||Swedish Expert Group (1971).

Table 2 Mean organ total mercury concentration showing the effects of fixation and storage

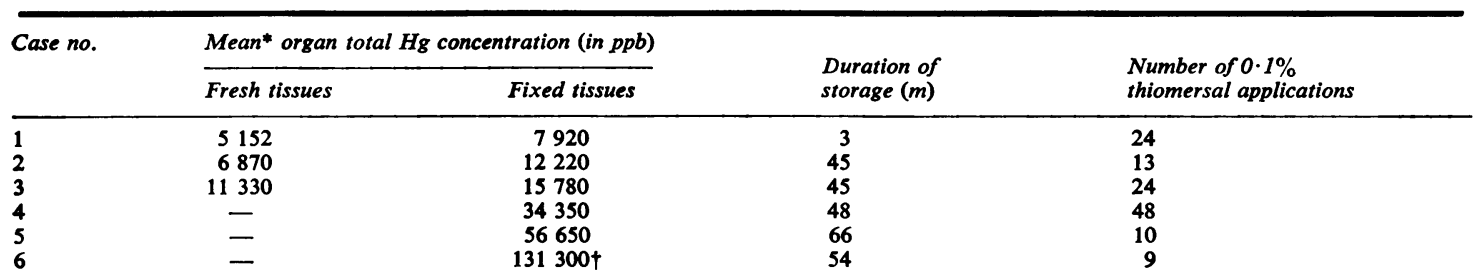

*This value is the mean of 4 samples of tissue, liver, kidney, spleen, and heart muscle or skeletal muscle as available. The values in individual tissues moved erratically, and the mean showed the trend most clearly.

tSamples of Case 6 showed evidence of drying at some time during storage.

of mercury had been absorbed, extrapolation to fresh tissue levels was not immediately possible. Complex factors appear to be involved, and any attempt at interpretation of mercury levels in fixed and stored tissues must be carefully controlled with other normal tissues fixed for a similar period in similar fixatives. A more detailed report will be published elsewhere.

\section{Discussion}

Whether the levels reported in Table 1 are acutely toxic or capable of producing chronic neurological damage in the newborn infant exposed perinatally as opposed to the fetus, older child, or adult, is unclear. Intrauterine exposure to methyl mercury (Study Group of Minimata Disease, 1968; Swedish Expert Group, 1971; Amin-Zaki et al., 1974a) causes damage in newborn infants at mercury levels similar to those associated with both acute and chronic neurological damage in older children and adults (Jalili and Abbasi, 1961; Damluji, 1962; Bakir et al., 1973; Suzuki et al., 1973; Rustam and Hamdi, 1974). Blood levels of about $400 \mathrm{ppb}$ are usually regarded as the threshold levels for the appearance of signs and symptoms in these groups, and levels of 1000 $1500 \mathrm{ppb}$ were invariably symptomatic. The thresh- old level for fatal poisoning appears to be around $3000 \mathrm{ppb}$ of blood.

Paradoxically, 4 infants exposed postnatally (Amin-Zaki et al., 1974b) did not exhibit signs or symptoms, though their blood levels were $>1000 \mathrm{ppb}$, and one was $>1500 \mathrm{ppb}$. This remarkable phenomenon is not easily explained, although part of the answer may lie in the difficulty of assessing neurological function in this group.

Although thiomersal is an ethyl mercury compound, it has similar toxicological properties to methyl mercury (Friberg and Vostal, 1972) and the long-term neurological sequelae produced by the ingestion of either methyl or ethyl mercury-based fungicides are indistinguishable (Kantarjian, 1961; Damluji, 1962; Bakir et al., 1973; Rustam and Hamdi, 1974). The clinical notes of the 6 cases studied, showed that 3 had developed unexplained vomiting, acidosis, or convulsions, but none of these findings alone is specific or indeed unusual in neonates.

We traced one of the survivors of this therapy. Full neurological examination at 10 years of age failed to show any evidence of the signs of minimal mercury damage such as visual field narrowing or glove and stocking paraesthesia. We are unable to comment on his intellectual development, though the school re- 
ports that he is restless, easily distracted, and not interested in schoolwork.

The use of mercurial antiseptics in the treatment of exomphalos appears to be declining rapidly, despite its recent advocation (Venugopal et al., 1976), undoubtedly because of the introduction of effective surgical procedures and a growing appreciation of the toxicity of organic mercurials.

Since it is clear that treatment of exomphalos by the application of alcoholic mercurial antiseptics can produce blood and tissue levels of mercury well above the threshold at which damage occurs in all other age groups, it is extremely unlikely that these infants escape neurological damage, which may be subtle. We therefore suggest that treated survivors should be examined neurologically and psychologically as a matter of urgency.

Organic mercurial antiseptics should be heavily restricted or withdrawn from hospital use, as the fact that mercury readily penetrates intact membranes and is highly toxic seems to have been forgotten. Equally effective and far less toxic broadspectrum antifungal and antibacterial topical antiseptics are currently available.

This work was supported in part by a center grant from the National Institute of Environmental Health Sciences, grant no. ES01247, and NIEHS grant no. ES01248, and in part on work performed under contract with the US Energy Research and Development Administration, University of Rochester Biomedical and Environmental Research Project and has been assigned report no. UR-3490-1050.

\section{References}

Amin-Zaki, L., Elhassani, S., Majeed, M. A., Clarkson, T. W. Doherty, R. A., and Greenwood, M. (1974a). Intrauterine methylmercury poisoning in Iraq. Pediatrics, 54, 587-595.

Amin-Zaki, L., Elhassani, S., Majeed, M. A., Clarkson, T. W., Doherty, R. A., and Greenwood, M. R. (1974b). Studies of infants postnatally exposed to methylmercury. Journal of Pediatrics, 85, 81-84.

Bakir, F., Damluji, S. F., Amin-Zaki, L., Murtadha, M., Khalidi, A., Al-Rawi, N. Y., Tikriti, S., Dhahir, H. I., Clarkson, T. W., Smith, J. C., and Doherty, R. A. (1973).
Methyl mercury poisoning in Iraq. An inter-university report. Science, 181, 230-241.

Damluji, S. (1962). Mercurial poisoning with fungicide Granosan M. Journal of the Faculty of Medicine (Baghdad), 4, 83-103.

Friberg, L., and Vostal, J. (1972). (Editors.) Mercury in the Environment-A Toxicological and Epidemiological Appraisal. CRC Press, Cleveland.

Giovanoli-Jakubczak, T., Greenwood, M. R., Smith, J. C., and Clarkson, T. W. (1974). Determination of total and inorganic mercury in hair by flameless atomic absorption, and of methylmercury by gas chromatography. Clinical Chemistry, 20, 222-229.

Grob, M. (1957). Lehrbuch der Kinderchirirgie. Thieme, Stuttgart.

Jalili, M. A., and Abbasi, A. H. (1961). Poisoning by ethyl mercury toluene sulphonanilide. British Journal of Industrial Medicine, 18, 303-308.

Kantarjian, A. D. (1961). A syndrome clinically resembling amyotropic lateral sclerosis following chronic mercurialism. Neurology, 11, 639-644.

Leenders, E., Adriaenssens, K., DeHauwere, R., and Van Heule, R. (1974). Omphalocoele and mercury intoxication. Presented at the British Association of Paediatric Surgeons Meeting, Berne.

Magos, L., and Clarkson, T. W. (1972). Atomic absorption determination of total inorganic and organic mercury in blood. Journal of the Association of Official Analytical Chemists, 55, 966-971.

Rustam, H., and Hamdi, T. (1974). Methyl mercury poisoning in Iraq. A neurological study. Brain, 97, 499-510.

Schippan, R., and Wehran, H. J. (1968). Mercurochrome treatment of omphalocoele (in German). Zeitschrift für Kinderchirurgie und Grenzgebiete (Stuttgart), 6, 319-326. Abstracted, Gellis, S. S.: Yearbook of Pediatrics, p. 467. Yearbook Medical Publishers, Chicago.

Stanley-Brown, E. G., and Frank, J. E. (1971). Mercury poisoning from application to omphalocoele. Journal of the American Medical Association, 216, 2144-2145.

Study Group of Minimata Disease (1968). Minimata Disease. Kumamoto University, Kumamoto, Japan.

Suzuki, T., Takemoto, T., Kashiwazaki, H., and Miyama, T. (1973). Metabolic fate of ethylmercury salts in man and animal. Mercury, Mercurials and Mercaptans, pp. 209-232. Ed. by M. W. Miller and T. W. Clarkson. Thomas, Springfield, Illinois.

Swedish Expert Group (1974). Nordisk Hygienisk Tidskrift, Suppl.

Venugopal, S., Zachary, R. B., and Spitz, L. (1976). Exomphalos and gastroschisis: a 10-year review. British Journal of Surgery, 63, 523-525.

Correspondence to Dr. D. G. Fagan, Histopathology Department, University Hospital, University Park, Nottingham. 